\title{
PRIORITAS PENENTUAN NILAI PENDIDIKAN KARAKTER DALAM PEMBELAJARAN SASTRA REMAJA
}

\author{
Burhan Nurgiyantoro dan Anwar Efendi \\ FBS Universitas Negeri Yogyakarta \\ email: burhan@uny.ac.id
}

\begin{abstract}
Abstrak: Penelitian bertujuan untuk mendeskripsikan sikap dan pendapat guru SMP/MTs terhadap penentuan prioritas nilai pendidikan karakter dalam pembelajaran sastra remaja, genre, dan strategi penyajian bahan ajar. Subjek penelitian adalah guru Bahasa Indonesia di DIY dengan sampel sebanyak 30 orang, hadir 24 orang, dari keempat kabupaten dan satu Kota Madya. Pengumpulan data dilakukan lewat angket, wawancara, dan sumbang saran di FGD. Data dianalisis dengan teknik deskriptif kualitatif dan penghitungan persentase. Hasil penelitian adalah sebagai berikut. (1) Penentuan prioritas nilai-nilai karakter perlu untuk memudahkan pemantauan, pengawasan, dan penilaian. Nilai karakter yang dipilih guru adalah nilai religius, jujur, cinta tanah air, peduli lingkungan, tanggung jawab, serta kreatif, gemar membaca, disiplin, dan mandiri. (2) Pemilihan genre tampak masih terpola pada pembagian sastra kanonik-dewasa, namun ia harus mencakup keseluruhan genre sastra remaja. (3) Penyajian bahan ajar ditekankan pada yang mendasarkan diri pada prinsip pembelajaran kontekstual dan multintelenjjens dengan teknik penilaian otentik.
\end{abstract}

Kata Kunci: Pengembangan bahan ajar, pendidikan karakter, sastra remaja

\section{DETERMINING THE PRIORITY OF THE CHARACTER EDUCATION VALUES IN ADOLESCENT LITERATURE TEACHING}

\begin{abstract}
This study aims to describe the attitude and opinions of SMP/MTs teachers on the determination of the priority of the character education values in adolescent literature teaching, genre, and strategies of the material presentation. The subjects were teachers teaching Bahasa Indonesia in Yogyakarta Special Province with a sample of 30 teachers (24 teachers were present) coming from the four regerncies and one municipality. The data were collected using questionnaires, interviews, and a discussion in a Forum Group Discussion. The data were analyzed using the qualitative descriptive technique and using proportion. The findings of the study were as follows: (1) the determination of the priority of the character education values was necessary for facilitating the monitoring, supervising, and assessing. The character values chosen by teachers were religious values, honesty, the love to the nation, care to the environment, responsibility, creativity, loving reading, discipline, and being selfdependent. (2) The choice of genre seemed to follow the categorization of adolescent-canonic literature, but it must cover all the adolescent literature genre. (3) The presentation of the materials emphasized on the contextual-based and multiintelligence-based teaching principles using authentic assessment.
\end{abstract}

Keywords: material development, character education, adolescent literature

\section{PENAHULUAN}

Sastra hadir karena masyarakat membutuhkannya. Sastra ditulis untuk komsumsi pembaca karena pembaca juga membutuhkan. Namun, harus dicatat bahwa kebutuhan akan sastra dan bacaan sastra berbeda dengan kebutuhan berbagai kebutuhan hidup yang lain terutama yang menyangkut unsur material. Ke- butuhan akan sastra terkait dengan kebutuhan batiniah, kebutuhan nonmaterial, kebutuhan afektif, kebutuhan pembentukan kepribadian. Kepuasan seseorang setelah membaca sastra lebih menyangkut kepuasan batiniah dan respon yang sering diberikan juga berupa respon afektif. 
Penikmat sastra meliputi segala umur, tingkatan emotif, tingkatan kognitif manusia, dan bahkan juga sosial. Pada intinya, semua manusia dari segala umur dan lapisan sosial berhak menikmati sastra. Mereka itulah pembaca sastra dan dunia mereka itu pula yang menjadi "bahan dasar" penulisan sastra. Jika "mereka" itu dibatasi pada dunia sekolah, mereka adalah semua peserta didik mulai dari tingkat Taman Kanak-Kanak, Sekolah Dasar, Sekolah Menengah, sampai Perguruan Tinggi. Artinya, mereka semua berhak memperoleh bacaan sastra yang sesuai dengan perkembangan emotif dan kognitifnya, atau berhak untuk memperoleh perhatian.

Namun, demikiankah fakta yang terjadi di masyarakat? Dunia sastra Indonesia tampak mengabaikan salah satu generasi, yaitu pembaca remaja, peserta didik setingkat SMP dan SMA/SMK, generasi sekolah menengah. Bahan pembelajaan sastra dalam buku-buku teks bahasa Indonesia dan buku penunjang lainnya belum dirancang untuk menjadi bacaan remaja. Impilikasinya, kurikulum bahasa dan sastra Indonesia, memaksa para remaja untuk membaca karya-karya sastra kanonik, karya-karya yang dianggap besar dan serius. Pijakan pembelajaran sastra di sekolah menengah adalah sastra Indonesia versi fakultas sastra, versi majalah kebudayaan dan majalah sastra, jurnal serius, penerbit idealis, dan versi seniman antiseni populer.

Sementara itu, berbagai genre sastra remaja, yang dikonsumsi oleh peserta didik sekolah menengah, secara mandiri dan apresiatif, masih dikucilkan dan direndahkan derajat estetiknya. Realitas remaja sekarang ini ditandai oleh adanya pilihan terhadap cerita remaja (komik, chikleet, teenlit) sebagai bacaan yang paling populer. Belum lagi bacaan-bacaaan fiksi, umumnya berupa cerpen, yang selalu menjadi menu favorit di setiap majalah atau tabloid remaja. Bacaan seperti itulah yang kini terlihat disenangi, bahkan digandrungi, oleh para remaja usia sekolah. Kenyataan seperti tidak dapat diabaikan begitu saja. Jika selama ini orang mengatakan remaja sekolah malas membaca buku-buku bacaan sastra, jangan- jangan itu lebih disebabkan tidak disenanginya bacaan itu oleh mereka.

Kurikulum baru, yakni kurikulum berbasis kompetensi (KBK, KTSP) dan kini Kurikulum 2013, memberikan kemungkinan yang terbuka untuk merealisasikan ha-hal di atas. Penerapan kurikulum baru tersebut diharapkan dapat mengenalkan remaja dengan karya-karya sastra yang dekat dengan dunianya. Dengan demikian, pembelajaran sastra tidak harus dipenuhi dengan ritual hafalan dan belenggu pengetahuan tentang sastra, yang seringkali menjadikan siswa merasa terasing dengan dunianya sendiri. Bahkan, kini mulai dirintis mewajibkan peserta didik pada tiap jenjang untuk membaca karya-karya sastra tertentu. Keadaan itu memberikan harapan untuk memasukkan sastra remaja sebagai salah bahan ajar yang perlu mendapat perhatian.

Selain itu, pembelajaran sastra berbasis sastra remaja juga dapat diarahkan pada upaya pelaksanaan pendidikan dan pengembangan karakter peserta didik. Masalah pentingnya pendidikan karakter anak di usia sekolah kini telah diyakini semua orang bagi pembentukan kepribadian yang juga berkarakter. Pendidikan karakter harus diintegrasikan ke dalam berbagai mata pelajaran sesuai dengan karakteristik tiap mata pelajaran itu. Artinya, berbagai mata pelajaran yang dibelajarkan di sekolah, juga mata pelajaran Bahasa Indonesia, harus mendukung tercapainya pembentukan karakter terpuji peserta didik. Inilah salah satu urgensi pengembangan bahan ajar sastra remaja untuk peserta didik remaja sekolah menengah.

Sebagai salah satu jenis kesenian, sastra sudah ada dalam perjalanan peradaban manusia. Proses pendidikan, pengenalan, dan pemahaman terhadap sastra akan dapat memperkaya manusia sebagai pribadi dalam dialog terus menerus dengan dunia manusia dan kemanusiaan. Dalam konteks inilah sastra berpotensi sebagai pemancar berbagai nilai dan dapat menjadi sumber pengilhaman tentang kebajikan (virtue) dan kebijakan (wisdom) (Hasan, 2002: 18). Dengan demikian, akan terjadi keseimbangan antara dimensi jasmaniah dan rohaniah dalam diri siswa sebagaimana yang dikehendaki 
dalam rumusan tujuan pendidikan nasional yang juga merupakan substansi pendidikan karakter. Kemampuan mengakrabkan diri dengan sastra pada gilirannya akan dapat mengarahkan manusia menuju pada sikap yang mencintai ketertiban, kelembutan hati, tajam pikiran, dan peka perasaan.

Salah satu karakteristik novel teenlit adalah bahwa mereka selalu berkisah tentang remaja, baik yang menyangkut tokoh-tokoh (utama) maupun permasalahannya. Para tokoh remaja itu hadir lengkap dengan karakter dan masalahnya: pertemanan, kisah cinta, putussambung cinta, impian, khayalan, cita-cita, konflik, dan lain-lain yang kesemuanya merupakan romantika dunia remaja. Umumnya teenlit mengangkat tokoh remaja perempuan yang kuat, tidak cengeng, mandiri dan tidak mudah diombang-ambingkan atau dilecehkan dalam pergaulan, baik dalam hal percintaan maupun persaingan meraih prestasi dengan remaja lakilaki (Kusmarwanti, 2005:111). Maka, tidak mengherankan jika pembaca remaja menjadi gandrung dan hanyut secara emosional seolaholah dirinya adalah bagian dari cerita itu.

Novel teenlit amat digandrungi oleh kaum remaja putri yang haus akan bacaan yang sesuai dengan kondisi kejiwaan mereka. Para remaja merasakan bahwa cerita novel teenlit dapat mewakili dan atau mencerminkan diri, dunia, cita-cita, keinginan, gaya hidup, gaya gaul, dan lain-lain yang menyangkut permasalahan mereka. Popularitas novel-novel teenlit antara lain dapat dilihat dari tingginya angka penjualan. Dalam waktu kurang lebih 15 bulan saja Penerbit Gramedia berhasil menjual sekitar 520 ribu eksemplar dari 34 judul novel teenlit yang diterbitkannya (Violine, 2009). Hal yang demikian jarang terjadi di Indonesia dan sudah luar biasa untuk ukuran Indonesia.

Dilihat dari sisi genre sastra, tampak bahwa sastra remaja juga berbeda dengan sastra anak, yaitu yang mencakup fiksi (cerita pendek, novel, cerita bersambung), puisi, drama, komik, sastra tradisional, serta buku informasi dan biografi. Hal itu tidak berbeda jauh dengan pembagian yang dikemukakan oleh Lukens (2003). Namun, Lukens tidak memasukkan drama dan komik sebagai bagian sastra anak/ remaja. Padahal, Grenby (2008:2) bahkan mengatakan bahwa komik merupakan karya yang paling banyak dibaca oleh anak dan remaja. Di pihak lain, Lukens menekankan pentingnya bacaan buku informasi (biografi dan bacaan informasi) sebagai bacaan sastra walau isinya sesuatu yang nyata, faktual, nonfiksi. Karya ini berisi fakta faktual, tetapi ditulis dengan stile sastra dan memang dimaksudkan sebagai bacaan sastra.

Di pihak lain, ada banyak pengertian karakter yang telah dikemukakan baik oleh para tokoh pendidikan maupun dalam dokumen resmi yang dikeluarkan oleh Negara, khususnya oleh Kemendikbud. Misalnya, Kemendiknas via Pusat Kurikulum (2010) karakter dimaknai sebagai watak, tabiat, akhlak, atau kepribadian seseorang yang terbentuk dari hasil internalisasi berbagai kebajikan (virtues) yang diyakini dan digunakan sebagai landasan untuk cara pandang, berpikir, bersikap, dan bertindak. Karakter tidak lain adalah tabiat atau kebiasaan untuk melakukan hal yang baik. Nilai-nilai karakter adalah sikap dan perila$\mathrm{ku}$ yang didasarkan pada norma dan nilai yang berlaku di masyarakat yang mencakup aspek spiritual, personal/kepribadian, sosial, dan lingkungan.

Kemendiknas $(2010 ; 2011)$ mengemukakan adanya 18 nilai karakter yang diharapkan dijadikan panduan pendidikan karakter di sekolah. Kedelapan belas nilai karakter yang dimaksud adalah (1) religius; (2) jujur, (3) toleransi, (4) disiplin, (5) kerja keras, (6) kreatif, (7) mandiri, (8) demokratif, (9) rasa ingin tahu, (10) semangat kebangsaan, (11) cinta tanah air, (12) menghargai prestais, (13) bersahabat/komunikatif, (14) cinta damai, (15) gemar membaca, (16) peduli lingkungan, (17) peduli social, dan (18) tanggung jawab.

Dilihat dari sisi pembelajaran, pembelajaran sastra harus secara aktif melibatkan peserta didik pada karya sastra secara langsung. Pembelajaran harus menggali potensi yang ada dalam diri peserta didik, membantu menemukan dan memecahkan masalah, membantu mereka berpikir lebih baik sebagai penghasil 
ilmu daripada sekadar penerima pasif fakta dan informasi. Jadi, pada prinsipnya pembelajaran yang bersifat menantang mereka untuk melangkah lebih jauh daripada sekadar apa yang dapat diberi nilai (Bellanca, 2011:6). Maka, pembelajaran menjadi lebih bermakna. Hal inilah yang juga ditekankan dalam pembelajaran kontekstual.

Pembelajaran kontekstual berangkat dari konsep pemikiran bahwa makna muncul dari hubungan antara isi dan konteksnya. Semakin banyak keterkaitan yang dapat ditemukan peserta didik dalam konteks yang luas, hal itu akan semakin bermakna bagi mereka. Penemuan makna dalam kegiatan pembelajaran adalah ciri utama dari pembelajaran kontekstual (Johnson, 2010:35). Makna itu sendiri dapat diartikan sebagai arti penting dari sesuatu yang dimaksud. Tujuan utama seseorang melakukan sesuatu adalah melihat dan atau menemukan makna yang ada di dalamnya. Hal-hal itulah yang kemudian dibawa ke pembelajaran sastra, khususnya sastra remaja kepada para remaja usia sekolah menengah. Mereka ditantang untuk menggeluti dan menemukan makna penting dan dikaitkan dengan kehidupan nyata.

\section{METODE}

Secara keseluruhan penelitian ini menggunakan desain penelitian dan pengembangan (Research and Development atau $R \& D$ ) (Borg \& Gall (1983). Penelitian dan pengembangan dalam dunia pendidikan adalah sebuah proses yang dipergunakan untuk mengembangkan dan memvalidasi produk-produk kependidikan. Penelitian ini adalah sebuah upaya untuk mengembangkan dan memvalidasi suatu produk pendidikan, yaitu model pengembangan buku panduan bahan ajar pembelajaran sastra remaja di sekolah (SMP/MTs). Namun, artikel ini "hanya" menyampaikan hasil yang terkait dengan kebutuhan guru terhadap nilai-nilai karakter yang perlu mendapat prioritas pembelajaran sastra remaja, genre, dan strategi penyajian bahan ajar.

Subjek penelitian adalah guru Bahasa Indonesia di DIY dengan sampel sebanyak 30 orang, yang hadir/menyerahkan kembali 24 orang, dari keempat kabupaten dan satu Kota Madya. Data penelitian dikumpulkan lewat angket, wawancara, dan sumbang saran dalam forum Fokus Group Discussion (FGD). Sesuai dengan jenis data yang diperoleh, data dianalisis dengan teknik kuantitatif dan kualitatif. Data angket dianalisis dengan teknik statistik deskriptif yang berwujud penghitungan frekuensi pemunculan dan persentase, sedang data verbal dari hasil wawancara, sumbang saran FGD, dan telaah literatur dianalisis dengan teknik deskriptif kualitatif khususnya yang berupa teknik kategorisasi.

\section{HASIL DAN PEMBAHASAN}

Ada dua sumber utama yang ditanyakan kepada para guru SMP/MTs terkait dengan pengembangan bahan sastra remaja, yaitu (1) prioritas aspek nilai pendidikan karakter, dan (2) genre, unsur struktural karya, dan strategi penyajian buku ajar.

\section{HASIL}

\section{Prioritas Pendidikan Karakter}

Aspek nilai pendidikan karakter yang dijadikan acuan adalah nilai-nilai pendidikan karakter sebagaimana yang disarankan Kemdiknas (2010) untuk dijadikan panduan pembelajaran pendidikan karakter dan budaya bangsa .yang terdiri atas delapan belas macam. Nilai-nilai itu tidak dibelajarkan secara terpisah dan tersendiri, melainkan diharapkan dapat dibelajarkan secara terpadu lewat berbagai mata pelajaran. Diharapkan nilai-nilai karakter tersebut semua dibelajarkan lewat berbagai strategi sesuai dengan strategi pembelajaran tiap mata pelajaran.

Namun, tentu saja dapat dilakukan dan dipilih nilai-nilai karate tertentu yang menjadi prioritas pembelajaran dalam suatu mata pelajaran. Hal itu disebabkan tampaknya tidak mudah jika semua nilai itu dibelajarkan sekaligus tanpa didukung oleh konteks dan strategi yang sesuai untuk tiap mata pelajaran. Pemilihan prioritas nilai antara satu mata pelajaran dan mata pelajaran yang tidak harus sama, tetapi tergantung pada konteks dan strategi tersebut. Penelitian pengembangan buku panduan bahan 
ajar pada tahun pertama ini dimaksudkan untuk menjaring sikap dan pendapat para guru SMP/MTs di DIY perihal pemilihan prioritas nilai-nilai karakter untuk pembelajaran sastra remaja.

Sikap dan pendapat para guru dijaring lewat pemberian angket, wawancara, dan curah pendapat lewat FGD. Setelah diolah dengan statistik deskriptif, hasil angket yang dimaksud ditunjukkan pada Tabel 1 dan Tabel 2 di bawah sesuai dengan pertanyaan yang diajukan yang kesemuanya terdiri atas 8 buah, 5 buah terkait dengan prioritas nilai pendidikan karakter, dan 3 buah terkait dengan genre, unsur struktural karya sastra, sumber pengambilan. Pemilihan skala prioritas hanya diambil tujuh tertinggi.

Selain itu, lewat penambahan isian angket yang sengaja disediakan, wawancara, dan sumbang saran sewaktu FGD dapat disimpulkan adanya masukan para guru sebagai berikut.

- Perihal prioritas nilai karakter yang dibelajarkan lewat pembelajaran sastra remaja: hampir semua guru menyebut nilai religius, jujur, cinta tanah air, peduli lingkungan, tanggung jawab; sebagian menambahkan nilai kreatif, gemar membaca, disiplin, dan mandiri.

- Perihal genre: semua guru menyebut genre cerita pendek, puisi, novel, drama, dan beberapa menambahkan komik dan biografi. Genre sastra yang dipilih sebaiknya bukan hanya karya sastra Indonesia, tetapi juga karya sastra terjemahan yang bagus kandungan isinya dan sesuai dengan dunia remaja.

- Perihal genre: bahan pembelajaran sebaiknya juga mengambil puisi-puisi dan cerpen remaja karya siswa yang merupakan puisi pemenang lomba seperti yang diselenggarakan oleh Balai Bahasa Yogyakarta. Alasan: isi sesuai dengan dunia remaja, bahasa bagus, dan komunikatif.

- Perihal unsur struktural: selain unsur struktural yang disebutkan dalam angket, sejumlah guru menambahkan unsur lain yang baik sebagai sarana pendidikan karakter, yaitu lewat pembuatan sinopsis, karya yang mengandung kandungan nilai-nilai karakter, nilai kehidupan, perwatakan, dan lain-lain.

- Perihal makna karya sastra: dipilih karya yang maknanya relatif mudah dipahami oleh anak usia remaja, karya yang tidak terlalu bermakan ambigu. Karya sastra adiluhung sering tidak mudah dipahami.

- Perihal sistematika pengembangan buku panduan pembelajaran: (1) dituliskan (ada) standar kompetensi, kompetensi dasar, indikator; (2) penyajian materi disertai ulasan, contoh-contoh yang jelas, dan latihan yang banyak; (3) uraian materi haruslah kontekstual, konsep jelas; (4) genre yang dibelajarkan lengkap: puisi, cerpen, novel, drama, dan lainnya dan perlu sedikit penjelasan teori.

\section{PEMBAHASAN \\ Prioritas Pendidikan Karakter}

Bahwa wacana pemasukan pendidikan kaarkter lewat berbagai mata pelajaran harus segera ditindaklanjuti dengan langkah konkret, tampaknya semua pihak yang terkait langsung dengan dunia pendidikan telah bersetuju. Hal itu semakin ditegaskan dengan dikeluarkannya buku panduan pembelajaran karakter di sekolah oleh Kemdiknas (2010) yang di dalamnya, selain mengandung unsur pendidikan nilai sebanyak delapan belas butir, juga ditunjukkan bagaimana pengimplementasiannya dalam berbagai mata pelajaran di sekolah menengah.

Hal yang perlu dicatat di sini adalah bahwa kedelapan belas unsur nilai pendidikan kaarkter yang disarankan untuk dibelajarkan tersebut berlaku untuk semua mata pelajaran. Artinya, semua mata pelajaran yang ada memunyai kewajiban dan tanggung jawab untuk ikut melaksanakannya agar hasilnya lebih maksimal. Hal itu juga akan mendukung penciptaan kultur sekolah yang lebih kondusif karena pelaksanaan pembelajaran nilai karakter tidak mungkin dilaksanakan secara parsial oleh sebagian mata pelajaran dan sebagaian sivitas akademika. Sebagai sebuah sistem pendidikan, semua komponen yang terkait yang menjadi subsistemnya harus secara bersama dilibatkan. 
Tabel 1. Tujuh Prioritas Pembelajaran Nilai Karakter pada Peserta Didik SMP/MTs lewat Pembelajaran Sastra Remaja

\begin{tabular}{|c|c|c|c|c|c|}
\hline \multirow[t]{2}{*}{ No. } & \multirow[t]{2}{*}{ Substansi Pertanyaan } & \multirow{2}{*}{$\begin{array}{l}\text { Jenis Nilai } \\
\text { Karakter }\end{array}$} & \multirow[t]{2}{*}{ Prioritas } & \multicolumn{2}{|c|}{$\begin{array}{l}\text { Jumlah Guru yang } \\
\text { Memilih }\end{array}$} \\
\hline & & & & Frekuensi & Persen \\
\hline \multirow[t]{7}{*}{1.} & \multirow{7}{*}{$\begin{array}{l}\text { Nilai karakter yang diutamakan } \\
\text { dibelajarkan kepada peserta didik }\end{array}$} & Jujur & I & 20 & 83 \\
\hline & & Religius & II & 19 & 79 \\
\hline & & Cinta tanah air & III & 16 & 67 \\
\hline & & Kreatif & IV & 13 & 54 \\
\hline & & Gemar membaca & $\mathrm{V}$ & 9 & 38 \\
\hline & & Disiplin & VI & 8 & 33 \\
\hline & & Tanggung jawab & VII & 8 & 33 \\
\hline \multirow[t]{7}{*}{2.} & \multirow{7}{*}{$\begin{array}{l}\text { Nilai karakter yang cocok } \\
\text { diintegrasikan dalam pembelajaran } \\
\text { sastra }\end{array}$} & Religius & I & 16 & 67 \\
\hline & & Jujur & II & 16 & 67 \\
\hline & & Cinta tanah air & III & 16 & 67 \\
\hline & & Peduli lingkungan & IV & 11 & 46 \\
\hline & & Kreatif & $\mathrm{V}$ & 10 & 42 \\
\hline & & Tanggung jawab & VI & 10 & 42 \\
\hline & & Kerja keras & VII & 9 & 38 \\
\hline \multirow[t]{7}{*}{3.} & \multirow{7}{*}{$\begin{array}{l}\text { Nilai karakter yang cocok } \\
\text { diintegrasikan dalam pembelajaran } \\
\text { sastra remaja }\end{array}$} & Jujur & I & 17 & 71 \\
\hline & & Religius & II & 16 & 67 \\
\hline & & Cinta tanah air & III & 15 & 63 \\
\hline & & Kreatif & IV & 10 & 42 \\
\hline & & Kerja keras & $\mathrm{V}$ & 8 & 33 \\
\hline & & Tanggung jawab & VI & 8 & 33 \\
\hline & & Peduli lingkungan & VII & 7 & 29 \\
\hline \multirow[t]{7}{*}{4.} & \multirow{7}{*}{$\begin{array}{l}\text { Nilai karakter yang diutamakan } \\
\text { lewat pembelajaran sastra remaja } \\
\text { di kelas }\end{array}$} & Jujur & I & 17 & 71 \\
\hline & & Disiplin & II & 13 & 54 \\
\hline & & Kreatif & III & 12 & 5 \\
\hline & & Religius & IV & 11 & 46 \\
\hline & & Tanggung jawab & $\mathrm{V}$ & 10 & 42 \\
\hline & & Cinta tanah air & VI & 9 & 38 \\
\hline & & Peduli lingkungan & VII & 7 & 29 \\
\hline \multirow[t]{7}{*}{5.} & \multirow{7}{*}{$\begin{array}{l}\text { Nilai karakter yang diutamakan } \\
\text { lewat pembelajaran sastra remaja } \\
\text { di luar kelas }\end{array}$} & Peduli lingkungan & I & 15 & 63 \\
\hline & & Peduli sosial & II & 15 & 63 \\
\hline & & Tanggung jawab & III & 10 & 42 \\
\hline & & Religious & IV & 10 & 42 \\
\hline & & Cinta tanah air & $\mathrm{V}$ & 9 & 38 \\
\hline & & Rasa ingin tahu & VI & 9 & 39 \\
\hline & & Kreatif & VII & 7 & 27 \\
\hline
\end{tabular}


Tabel 2. Prioritas Pembelajaran Genre, Unsur Struktural, dan Sumber Bahan

\begin{tabular}{|c|c|c|c|c|c|}
\hline \multirow[t]{2}{*}{ No. } & \multirow[t]{2}{*}{ Substansi Pertanyaan } & \multirow[t]{2}{*}{ Jenis Nilai Karakter } & \multirow[t]{2}{*}{ Prioritas } & \multicolumn{2}{|c|}{$\begin{array}{l}\text { Jumlah Guru yang } \\
\text { Memilih }\end{array}$} \\
\hline & & & & Frekuensi & Persen \\
\hline \multirow[t]{7}{*}{1.} & \multirow{7}{*}{$\begin{array}{l}\text { Genre sastra remaja yang } \\
\text { diutamakan dibelajarkan di } \\
\text { sekolah }\end{array}$} & Cerita pendek & I & 24 & 100 \\
\hline & & Drama & II & 24 & 100 \\
\hline & & Puisi & III & 23 & 96 \\
\hline & & Novel & IV & 19 & 79 \\
\hline & & Biografi & V & 13 & 54 \\
\hline & & Komik & VI & 11 & 46 \\
\hline & & Buku Informasi & VII & 5 & 21 \\
\hline \multirow[t]{6}{*}{2.} & \multirow{6}{*}{$\begin{array}{l}\text { Unsur sastra yang cocok untuk } \\
\text { pembelajaran karakter }\end{array}$} & Tema dan amanat & I & 23 & 96 \\
\hline & & Tokoh & II & 23 & 96 \\
\hline & & Latar & III & 20 & 83 \\
\hline & & Alur & IV & 16 & 67 \\
\hline & & Sudut pandang & V & 15 & 63 \\
\hline & & Stile & VI & 10 & 42 \\
\hline \multirow[t]{4}{*}{3.} & \multirow{4}{*}{$\begin{array}{l}\text { Sumber pengambilan bahan ajar } \\
\text { sastra remaja }\end{array}$} & Koran/majalah & I & 22 & 92 \\
\hline & & Internet & II & 21 & 88 \\
\hline & & Perpustakaan sekolah & III & 17 & 71 \\
\hline & & Milik sendiri & IV & 17 & 71 \\
\hline
\end{tabular}

Bahwa kedelapan belas nilai tersebut dibelajarkan semua lewat satu mata pelajaran, hal itu dapat saja dilakukan tergantung guru sebagai pelaksana kegiatan pembelajaran. Namun, yang pasti pengamatan terhadap proses dan hasil pembelajaran, internalisasi dan pembudayaan terhadap kedelapan belas nilai sudah pasti cukup merepotkan. Untuk itu, penentuan prioritas, fokus pada nilai karakter tertentu, tampak lebih dimungkin dan lebih memudahkan pemantauan dan evaluasi efektivitas pembelajarannya. Artinya, suatu mata pelajaran, misalnya Bahasa Indonesia, diperbolehkan menekankan, memfokuskan, atau memrioritaskan nilai pendidikan karakter tertentu dalam pelaksanaan pembelajaran. Di pihak lain, mata-mata pelajaran yang lain, boleh memfokuskan diri pada nilai yang sama, ada yang sama, atau yang lain.

Salah satu pertimbangan pemilihan pemrioritasan nilai-nilai karakter itu adalah kesesuaian dengan masing-masing mata pelajaran. Semua nilai yang dicantumkan memang baik, namun ada nilai-nilai tertentu yang lebih cocok untuk suatu mata pelajaran.

Untuk menentukan prioritas nilai-nilai yang dimaksud, penelitian ini menjaring sikap, tanggapan, dan pendapat para guru SMP/MTs di DIY yang hasilnya sebagaimana ditunjukkan pada Tabel 1. Hasil penelitian pada tahap ini dimaksudkan untuk dijadikan dasar pilihan fokus pendidikan karakter dalam pengembangan bahan ajar pembelajaran sastra remaja. Para guru yang notabene adalah guru para remaja itu telah menentukan nilai-nilai yang menurutnya mendesak dan penting untuk lebih ditekankan pembelajarannya. Harus juga dipahami bahwa pengertian prioritas, fokus, tidak perlu diartikan sebagai tidak menganggap penting nilai-nilai yang lain.

Angket dan wawancara sengaja dilakukan dengan menanyakan nilai-nilai karakter yang mencakup (1) nilai karakter yang diutamakan dibelajarkan kepada peserta didik; (2) nilai karakter yang cocok diintegrasikan dalam pembelajaran sastra; (3) nilai karakter yang 
cocok diintegrasikan dalam pembelajaran sastra remaja; (4) nilai karakter yang diutamakan lewat pembelajaran sastra remaja di kelas; dan (5) nilai karakter yang diutamakan lewat pembelajaran sastra remaja di luar kelas. Pertanyaan kedua sampai kelima sudah fokus untuk tujuan pembelajaran sastra dan sastra remaja.

Tampak bahwa pada umumnya guru lebih memilih nilai-nilai religius, jujur, cinta tanah air, peduli lingkungan, dan tanggung jawab yang mesti mendapat prioritas dalam pembelajaran sastra remaja. Ada sejumlah nilai lain yang juga dipilih, namun arus utama guru adalah pada nilai-nilai itu. Hal itu mengandung konsekuensi bahwa dalam hal pengembangan bahan ajar sastra remaja, bahan karya sastra yang dipilih harus difokuskan pada berbagai karya dari berbagai genre yang mengandung unsur-unsur nilai pendidikan tersebut. Jadi, hasil angket, wawancara, dan curah pendapat itu memberikan kejelasan pemilihan fokus penentuan nilai karakter.

Nilai religius, kejujuran, dan cinta tanah air adalah ketiga nilai yang banyak dipilih untuk diprioritaskan pembelajarannya oleh guru. Keadaan itu dapat dipahami karena semua orang, bahkan guru sebagai guru dan sebagai orang tua, pasti mengehndaki peserta didik dan anak-anaknya bersikap dan berperilaku religius. Apalagi kita hidup di Negara yang juga berdasarkan nilai-nilai ketuhanan. Demikian juga nilai kejujuran. Apalah arti hidup jika kita, anak didik kita, dan bangsa kita hidup dalam kondisi yangdilandasi prinsip kejujuran? Hal yang menarik untuk dicatat adalah pendapat guru yang juga menekankan nilai cinta tanah air. Hal ini penting sekali, kata mereka baik yang terlihat dalam angket, wawancara, maupun sumbang saran di FGD, mengingat mereka masih usia remaja untuk menyadarkan dan mengembangkan perasaan nasionalisme.

Keadaan itu juga sejalan dengan penelitian yang dilakukan Zuchdi dkk (2010:7-10) tentang model pendidikan karakter terintegrasi dalam bidang studi di Sekolah Dasar. Mereka juga menentukan fokus-fokus nilai yang dipilih berdasarkan sikap dan tanggapan guru, kepala sekolah, dan orang tua siswa yang memilih nilai-nilai kesabaran, kerja sama, kepedulian, kejujuran, ketaatan beribadah, kediplinan, dan kenyamanan semua warga sekolah. Setelah dilakukan pembelajaran secara komprehensif lewat berbagai bidang studi, misalanya diketahui ada sedikit peningkatan dalam hal ketaatan beribadah dan peningkatan nilai kejujuran. Peningkatan nilai kejujuran terlihat lebih intensif. Peningkatan nilai ini antara lain terlihat dalam hal kantin kejujuran yang tidak merugi, menyerahkan temuan barang hilang, mengembalikan kepada pemiliknya, dan lain-lain.

Dalam penelitian tersebut juga diperoleh fakta mengenai adanya peningkatan dari penciptaan kultur sekolah antara sebelum dan sesudah perlakuan. Peningkatan kultur itu terlihat antara lain pada peningkatan ketertiban, kedisiplinan, kejujuran, dan rasa persaudaraan. Misalnya, nilai-nilai tersebut sebelumnya ada yang masih dalam kategori kurang, tetapi kemudian menjadi cukup, hampir baik, dan baik. Hal itu sekaligus menunjukkan bahwa usaha penanaman pendidikan karakter haruslah secara bersamaan disertai dengan usaha penciptaan kultur sekolah karena secara bersama akan memberikan dampak yang lebih signifikan.

Dalam pengembangan ESQ yang menekankan pengelolaan kecerdasan spiritual, emosional, dan intelektual, Agustian (2013) juga terlihat memfokuskan pada capaian nilai karakter tertentu, yaitu tujuh nilai inti tentang kejujuran, tanggung jawab, visioner, disiplin, kerjasama, adil, dan peduli. Itu adalah dan "hanyalah" nilai-nilai karakter yang menjadi fokus dalam pelatihan motivasi karena secara faktual juga mesti melibatkan nilai-nilai karakter yang lain. Dengan penentuan fokus dan atau prioritas nilai-nilai itu justru akan membuat kita menjadi lebih fokus dalam usaha pembelajaran karena yang dilakukan menjadi lebih konkret dan memusat.

Pengembangan bahan ajar pada hakikatnya bagian dari pengembangan kurikulum secara keseluruhan. Jika berharap lulusan jenjang pendidikan tertentu memiliki kualifikasi karakter yang dikehendaki, kurikulum yang didesain untuk mencapai tujuan itu harus juga dikembangkan berdasarkan prinsip nilai-nilai 
karakter. Tepatnya, bahan pembelajaran yang dikembangkan harus memenuhi tuntutan itu. Artinya, desain dan pengembangan bahan ajar harus secara sengaja didesain untuk menghasilkan lulusan yang berbudaya dan berkarakter yang sesuai dengan nilai-nilai yang dikehendaki oleh masyarakat. Penyebutan 'masyarakat' di sini dapat dipersempit lewat sikap, pendapat, dan pemilihan nilai-nilai karakter sebagaimana dilakukan oleh para guru di atas.

Selain penentuan berfokus nilai karakter tertentu, pengembangan bahan ajar pembelajaran sastra remaja juga berprinsip pengembangan kurikulum yang berbasis budaya. Gufron (2011:56-57) mengemukakan ciri kurikulum yang berbasis budaya adalah (1) berorientasi pada pembentukan manusia berwatak, beradab, dan bermartabat; (2) bahan pembelajaran dikembangkan dari berbagai sumber; (3) berprinsip pada pembudayaan segenap potensi peserta didik; dan (4) sistem penilaian ditekankan pada proses dan hasil sekaligus. Jadi, proses pendidikan yang diselenggarakan tidak lain adalah proses pembudayaan nilai-nilai, proses internalisasi nilai-nilai, lewat bahan ajar pada mata-mata pelajaran yang dibelajarkan. Hal itu tampak relevan dengan pembelajaran sastra karena sastra dapat dipandang sebagai budaya dalam tindak.

\section{Penentuan Genre Sastra}

Genre sastra yang selama ini dikenal oleh guru adalah dan hanyalah mencakup tiga jenis, yaitu puisi, fiksi (cerita pendek dan novel), serta drama. Namun, sebenarnya genre itu lebih banyak ditujukan pada sastra dewasa, sastra kanonik adiluhung yang selama ini dikenal di masyarakat luas. Genre itu pula yang selama ini menjadi acuan pembelajaran sastra di sekolah. Padahal, pada kenyataannya ada perbedaan genre antara genre sastra dewasa dan genre remaja atau sastra anak. Di Indonesia genre sastra anak dan remaja memang baru berkembang dan kemudian menjadi popular akhir-akhir ini sehingga wajar jika para guru sekolah menengah belum banyak yang memahaminya.

Secara garis besar Lukens (2003) mengelompokkan genre sastra anak ke dalam enam macam, yaitu realisme, fiksi formula, fantasi, sastra tradisional, puisi, dan buku informasi dan biografi dengan masing-masing memunyai beberapa jenis lagi. Genre drama sengaja tidak dimasukkan karena menurutnya, drama baru lengkap setelah dipertunjukkan dan ditonton, dan bukan semata-mata urusan bahasa-sastra. Demikian juga halnya komik yang juga belum dianggap sebagai bagian dari genre sastra anak. Padahal, faktanya komik juga merupakan salah satu genre sastra yang bahkan amat tinggi popularitas karena begitu banyak peminat anak dan remaja untuk membacanya.

Genre sastra anak dan remaja memasukkan genre drama dan komik. Jadi, genre meliputi puisi, fiksi (cerita pendek dan novel), drama, buku informasi dan biografi, komik, bahkan juga sastra tradisional. Pembagian ini mencoba memasukkan fakta yang berkembang di masyarakat bahwa terdapat sekian macam genre yang kemudian diakui sebagai genre sastra anak dan remaja. Pembagian ini pula yang kemudian ditawarkan kepada guru untuk memilih genre mana saja yang sebaiknya dipilih sebagai bahan ajar pembelajaran sastra remaja. Hasil pilihan guru ditunjukkan pada Tabel 2.

Bahwa hampir semua guru memilih genre cerita pendek, drama, dan puisi, hal itu dapat mudah dipahami karena ketiga genre itulah yang selama ini lebih dikenal. Selain cerita pendek, genre fiksi yang lain, yaitu novel, juga masih banyak dipilih. Namun, pembelajaran novel di sekolah tampaknya dinilai cukup merepotkan karena novel sulit dihadirkan secara fisik di kelas untuk dibicarakan dalam satu pertemuan. Hal itu berbeda dengan genre puisi dan cerpen, yang bentuknya yang relatif pendek, masih memungkinkan untuk dihadirkan semuanya skaligus. Terlepas dari kesulitan itu, tampak bahwa ketiga genre itulah yang mesti dilibatkan dalam usaha pengembangan bahan ajar. Ketiga genre itu sudah amat diakrapi oleh para guru dan peserta didik.

Fakta bahwa guru belum memahami jangkauan sastra remaja yang lebih luas disbanding sekadar genre "tradisional" tersebut adalah bahwa sebagian mereka belum berani secara konkret memasukkan genre yang lain, 
yaitu biografi, komik, dan buku informasi ke dalam pemilihan bahan ajar. Ketiga genre itu adalah khas sastra anak dan remaja. Pada masa lalu umumnya guru menolak membicarakan dan memasukkan komik sebagai salah satu genre sastra yang mesti dibelajarkan. Demikian juga halnya dengan sastra popular yang kini dikenal dengan sebutan teenlit. Namun, sejalan dengan munculnya era postmodern yang menolak diskriminasi atas genre-genre tersebut, karya komik dan sastra popular juga "tidak ada salahnya" dibelajarkan. Apalagi jika mengingat kenyataan bahwa di masyarakat justru genre itulah yang lebih banyak dibaca oleh remaja.

Dalam rangka pengembangan bahan ajar pembelajaran sastra remaja, genre yang merupakan khas sastra anak dan remaja tersebut mesti dilibatkan. Hal itu berdasarkan fakta bahwa tidak sedikit karya jenis itu yang amat bernilai. Jenis biografi misalnya, adalah karya sastra yang mengangkat para tokoh penting di bidangnya baik tokoh dari Indonesia maupun dunia. Pembelajaran sastra biografis dapat memancing sikap positif peserta didik untuk mengembangkan nilai karakter.

Buku informasi, di pihak lain, berisi fakta pengetahuan, misalnya temuan berbagai ilmu, perihal binatang dan tanaman, banyak memberikan informasi penting terkait ilmu pengetahuan. Buku informasi adalah buku tentang fakta berbagai keilmuan dan informasi lain yang ditulis dengan stile sastra (Lukens, 2003), maka kehadirannya bagus untuk mengimbangi karya fiksi yang fiktif. Demikian juga halnya dengan komik. Ketika berbicara tentang komik, kita tidak harus hanya terfokus pada karyakarya komik seperti Doraemon, Crayon Sinchan, Sponge Bob, dan lain-lain. Komikkomik itu dan film kartunnya amat digemari anak-anak dan remaja yang terbukti sudah sekian puluh tahun dari kemunculannya kini tetap eksis. Selain komik-komi itu, ada juga komik-komik lain yang diangkat dengan "bahan dasar" biografi dan informasi faktual. Jika dilihat dari segi bentuk, karya-karya itu termasuk genre komik, namun jika dilihat dari sisi kandungan isi, mereka adalah biografi dan buku infromasi. Apa pun penamaan yang diberikan kepadanya, karya-karya itu tetap saja bagus untuk dibaca dan dijadikan bahan ajar kepada remaja.

\section{Penyajian Bahan Ajar}

Buku panduan yang dikembangkan bukan merupakan buku pegangan wajib, tetapi lebih merupakan buku pengayaan karena buku pegangan sudah dikembangkan oleh tim yang di bawah Kemendiknas. Dengan demikian, sistematika penyusunan buku tidak harus sama seperti sistematika buka ajar yang ada selama ini. Para guru yang dimintai pendapat juga telah memberikan usulan sebagaimana ditunjukkan di atas yang terlihat masih berpola buku ajar tradisional. Namun, hal itu tidak berarti tidak baik. Sesuatu yang mungkin dapat ditambahkan adalah sesuatu yang membuat penyajian menjadi tidak monoton, terasa baru, menunjang kemampuan bersastra, dan sekaligus mendukung usaha pendidikan karakter peserta didik.

Selain berdasarkan pertimbangan kandungan unsur pendidikan karakter dan genre sastra, pengembangan bahan ajar sastra remaja juga dilakukan dengan pertimbangan ketepatan strategi penyampaian, yaitu strategi agar peserta didik benar-benar masuk ke dalam karya sastra baik secara emosional maupun intelektual. Karya sastra terutama hadir untuk dinikmati dan dihayati dengan cara-cara yang menyenangkan dan bukan sebagai ilmu pengetahuan yang mesti dianalisis dengan kemampuan intelektual semata. Intinya, peserta didik harus membaca karya secara langsung dan dari sini diharapkan muncul sikap positif untuk belajar berbagai masalah kehidupan lewat tokoh cerita. Sekali lagi, sastra adalah budaya dalam tindak, maka berbagai nilai karakter yang ditanamkan kepada peserta didik mesti diperoleh lewat tingkah laku, sikap, tindakan, cara berpikir dan bersikap para tokoh, dan bukan lewat indoktrinasi.

Dengan demikian, peserta didik seolaholah belajar langsung perihal kehidupan, kehidupan yang diidealkan. Untuk itu, penyediaan bahan ajar terpilih haruslah cukup sehingga mampu menyediakan pilihan-pilihan terhadap adanya selera yang tidak sama pada peserta didik terhadap bacaan sastra. Bahan ajar 
yang berwujud puisi, cerpen, drama pendek, atau karya-karya lain yang tidk relatif panjang memang lebih praktis. Namun, bagaimanapun karya novel teenlit yang relatif panjang tidak boleh diabaikan. Persoalannya adalah bagaimana menyediakan, menghadirkan, dan menugasi peserta didik agar "terpaksa" mau membaca.

Tidak berbeda halnya dengan praktik pembelajaran di kelas, penyajian bahan ajar akan dilakukan dengan menempatkan pendekatan pembelajaran kontekstual (CTL, Contextual Teacing and Learning) (Johnson, 2010) dan multiintelejen (Bellanca, 2011) sebagai pijakan utama. Hal itu dimaksudkan agar pembelajaran terkait dengan kenyataan kehidupan di masyarakat dan sekaligus "menggarap" kemampuan intelegensi agar tampil secara maksimal. Maka, tugas-tugas latihan, membuat ringkasan, proyek, dan lain-lain yang mensyaratkan peserta didik melakukan berbagai aktivitas kinerja yang bermakna, walau dengan cara yang sederhana, adalah sesuatu yang tidak terelakkan. Berbagai tugas tersebut yang dikenal dengan tugas atau penilaian otentik amat dianjurkan penggunaannya dalam kurikulum KTSP dan lebih ditekankan lagi pada Kurikulum 2013.

Penelitian ada kesamaannya dengan penelitian pengembangan Suryanto, dkk. (2013) tentang model pendidikan budi pekerti berbasis cerita anak untuk penanaman nilai etis-spiritual kepada siswa sekolah dasar yang juga bertujuan menghasilkan produk buku bahan ajar. Mereka mengemukakan bahwa kandungan buku yang dihasilkan itu sebagai berikut. (1) Petunjuk belajar bagi siswa/guru; (2) kompetensi yang akan dicapai; (3) isi materi pembelajaran; (4) informasi tentang identifikasi nilai-nilai etisspiritual berwawasan pendidikan karakter; (5) pertanyaan-pertanyaan terkait isi materi untuk mengembangkan aspek kognitif, psikomotorik, dan afektif siswa. Materi ajar disusun dengan mempertimbangkan tingkat keterbacaan dan daya pikir siswa. Dengan cara demikian, diharapkan materi ajar ini mudah dipahami, direspons, dan diproses oleh siswa sehingga mempermudah pencapaian tujuan pembelajaran.

\section{PENUTUP}

- Pembelajaran pendidikan karakter lewat mata pelajaran Bahasa Indonesia, khususnya pembelajaran sastra remaja di SMP/MTs, sebagaimana halnya dengan mata-mata pelajaran yang lain, perlu adanya penentuan prioritas-prioritas pada nilai-nilai karakter tertentu. Hal itu dimakudkan agar guru dan peserta didik dapat lebih memfokus pada sejumlah nilai dan lebih memudahkan pemantauan, pengawasan, dan penilaiannya. Namun, hal itu tidak perlu diartikan abai terhadap nilai-nilai karakter yang lain yang tidak menjadi fokus. Para guru SMP/MTs di DIY menyetujui sejumlah prioritas nilai yang mesti mendapatkan perhatian utama adalah nilai-nilai religius, jujur, cinta tanah air, peduli lingkungan, dan tanggung jawab, serta sejumlah nilai lain pada urutan berikutnya, yaitu nilai kreatif, gemar membaca, disiplin, dan mandiri. Daftar nilai yang dipilih untuk dibelajarkan sengaja diambil dari Kemendiknas (2010) yang disarankan untuk dibelajarkan di sekolah.

- Pemilihan genre sastra remaja yang mesti dibelajarkan oleh para guru tampak masih terpola pada pembagian sastra kanonikdewasa. Tampaknya, mereka belum paham bahwa sastra anak dan remaja memiliki genre yang lebh luas jangkauananya. Genre sastra yang dipilih untuk dibelajarkan haruslah mencakup keseluruhan genre walau prioritas mungkin masih pada genre arus-utama, yaitu puisi, fiksi, dan drama. Pada kenyataannya, genre komik dan buku informasi membanjir di pasaran dan tampak diminati oleh para remaja.

- Penyajian bahan ajar pembelajaran sastra remaja ditekankan pada penyajian bacaan, pemberian tugas, dan latihan yang mendasarkan diri pada prinsip pembelajaran kontekstual dan multiintelejen. Dengan begitu, selain terkait dengan kehidupan faktyal di masyarakat, potensi pada diri peserta didik juga dapat dimaksimalkan. 
Untuk itu, teknik penilaian harus mempergunakan tugas-tugas otentik.

\section{UCAPAN TERIMA KASIH}

Ucapan terima kasih pertama disampaikan kepada sponsor yang telah membiayai penelitian ini, yaitu Direktorat Penelitian dan Pengabdian kepada Masyarakat Ditjen Dikti. Kedua, ucapan terima kasih juga disampaikan kepada pimpinan LPPM dan seluruh jajarannya yang telah memfasilitasi penelitian, para guru SMP di DIY yang menjadi responden, sejawat sahabat berdiskusi, dan pihak-pihak lain membantu kerja ini baik secara langsung maupun tidak langsung. Mudahan-mudahan semua itu sekaligus juga bernilai ibadah. Amin.

\section{DAFTAR PUSTAKA}

Agustian, Ary Ginanjar. 2012. ESQ, Emotional Spiritual Quotient, The ESQ Way 165. Jakarta: Arga Tilanta.

Bellanca, James. 2011. 200+ Strategi dan Proyek Pembelajaran Aktif untuk Melibatkan Kecerdasan Siswa. Jakarta: Indeks (Penerjemah: Siti Mahyuni).

Borg, Walter R. \& Meredith Damien Gall. 1983. Educational Research, an Introduction. New York: Longman.

Grenby, Mathew O. 2008. Childrens Literature. Edinburgh. Edinburgh University Press.

Gufron, Anik. 2010. Integrasi Nilai-nilai Karakter Bangsa pada Kegiatan Pembelajaran, dalam Cakrawala Pendidikan, Jurnal Ilmiah Pendidikan, Th.XXIX, Mei, hlm. 13-24.

Gufron, Anik. 2011. "Desain Kurikulum yang Relevan untuk Pendidikan Karakter", Cakrawala Pendidikan, Jurnal Ilmiah Pendidikan, Th.XXX, Mei, hlm. 52-63.

Hasan, Fuad. 2002. "Catatan Perihal Sastra dan Pendidikan" dalam Warta HISKI Desember 2002.

Johnson, Elaine B. 2010. Contextual Teaching and Learning, Menjadikan Kegiatan Be-
lajar-Mengajar Mengasyikkan dan Bermakna. tanpa kota: MLC.

Kemendiknas. 2010. Pengembangan Budaya dan Karakter Bangsa, Pedoman Sekolah. Jakarta: Badan Penelitian dan Pengembangan, Pusat Kurikulum.

Kemendiknas. 2011. Panduan Pelaksanaan Pendidikan Karakter. Badan Penelitian dan Pengembangan, Pusat Kurikulum dan Perbukuan.

Kusmarwanti. 2005. "Teenlit dan Budaya Menulis di Kalangan Remaja", dalam Pangesti Widarti (ed). Menuju Budaya Menulis, suatu Bunga Rampai. Yogyakarta: Tiara Wacana.

Lukens, Rebecca J. 2003. A Critical Handbook of Children's Literature. New York: Longman.

Suryaman, Maman. 2010. "Pendidikan Karakter melalui Pembelajaran Sastra", dalam $\mathrm{Ca}$ krawala Pendidikan, Jurnal Ilmiah Pendidikan, Th.XXIX, Mei, hlm. 112-126.

Suryanto, Edy, Raheni Suhita, dan Yant Mujiyanto. 2013. "Model Pendidikan Budi Pekerti Berbasis Cerita Anak untuk Penanaman Nilai Etis-Spiritual", Litera, Jurnal Penelitian Bahasa, sastra, dan Pengajarannya, Vol. No. 2, Oktober, hlm. 239-249.

Violine, Melody. 2009. Gaya Bahasa Teenlit: Pilihan dan Pembentukan Kata. http://nyanyianbahasa.wordpress.com.

Diunduh, 28 November 2012.

Zuchdi, Darmiyati dkk. 2010. "Pengembangan Model Pendidikan Karakter dalam Pembelajaran Bidang Studi di Sekolah Dasar" dalam Cakrawala Pendidikan, Jurnal Ilmiah Pendidikan, Th.XXIX, Mei, hlm. 1-12.

Zuchdi, Darmiyati dkk. 2012. Pendidikan Karakter: Konsep Dasar dan Implementasi di Perguruan Tinggi. Yogyakarta: UNY Press. 